\title{
Development and Difference
}

Pragmatism and the Social Process

\section{Andrew Abbott}

\section{(2) OpenEdition Journals}

Electronic version

URL: http://journals.openedition.org/ejpap/639

DOI: 10.4000/ejpap.639

ISSN: 2036-4091

Publisher

Associazione Pragma

\section{Electronic reference}

Andrew Abbott, « Development and Difference », European Journal of Pragmatism and American Philosophy [Online], VIII-2 | 2016, Online since 16 January 2017, connection on 30 April 2019. URL http://journals.openedition.org/ejpap/639; DOI : 10.4000/ejpap.639

This text was automatically generated on 30 April 2019.

\section{(c) $($ ) $\odot$ (8)}

Author retains copyright and grants the European Journal of Pragmatism and American Philosophy right of first publication with the work simultaneously licensed under a Creative Commons AttributionNonCommercial-NoDerivatives 4.0 International License. 


\title{
Development and Difference
}

\author{
Pragmatism and the Social Process
}

\author{
Andrew Abbott
}

1 A central premise of the Chicago School of Sociology has been its insistence that social facts are located in place and time. The meaning of a social fact is always relative to its context of other social facts. Methodologically, this rule has implied a certain hesitancy about the decontextualized approach characteristic of survey analysis. Substantively, it has taken shape in a focus on "natural history" and "natural areas," that is, on typical developments over time and typical differences between parts of the social world (Abbott 1997).

Development in time and difference in space are closely related. The idea of personal development seems natural and unproblematic as a result of our everyday familiarity with narratives of experience. But narrative cannot be a complete account of social life, because the past does not reach out and influence the present, as it does so often in our stories. The influence of the deep past on the present must come through the traces that that deep past has left in succeeding presents. Causality happens in the present moment: as George Herbert Mead says, the world is a world of events. This means that present differences - both within the self and beyond it - are the present traces of past events. In some sense, difference in the present is then the correlative, the trace, the record, of past events, and therefore development and difference are at the deepest level two sides of the same phenomenon - of process itself.

In practice, however, these problems are usually investigated separately, and indeed we might expect them to have separate sources. For the Chicago School in particular, a likely influence would be the pragmatists. The Chicago School took shape in the years pragmatism was strongest at Chicago, and indeed there were extremely close relations between W. I. Thomas - the central progenitor of the Chicago School - and his pragmatist philosopher colleagues John Dewey and George Herbert Mead. Moreover, while the topics of development and difference are are largely absent from the earlier pragmatists Peirce and James, they are important for Mead and central for Dewey.

In this paper I shall examine how the pragmatists regarded the context of a single self in time (the problem of personal development over the life course) and the context of a 
single self in social space (the problem not only of surrounding individuals but also of surrounding and fundamentally different groups). After a quick glance at the ontologies of the earlier pragmatists, I discuss the problems of individual development and social difference as they emerged society-wide during and after the first pragmatist generation. Having specified these problems, I can set the second pragmatist generation in the context they provide. The paper concludes with a discussion of the centrality of accounts of development and difference in a processualized social ontology.

The usual disclaimers apply. I do not provide a definitive account. This is a reading and reflection on a possible linkage, not a precise exercise in intellectual history. The principal focus is on the pragmatist authors, not on the Chicago School, whose interest in these topics I have discussed extensively elsewhere. But as a theorist in the Chicago tradition, I am principally interested in development and difference because of their twofold centrality to the processual account of the social world. By reading (especially) Mead and Dewey in this light, I hope to find new issues and problems that require theoretical clarification. As for the evolution of pragmatist thought in itself, that is a topic that others are better equipped to undertake.

\section{The Earlier Pragmatists and the Great Watershed}

Peirce's account of ontology, as of nearly everything else, embeds ontology within the master analysis of signs. The result is an epistemological ontology, if we can imagine such a thing; observable phenomena are defined in terms of their logical structure. Pierce's purely logical approach disregards the passage of historical (that is, particular) time, whether in the lives of individual humans, or in the evolution of "larger histories," or, ultimately, in the evolution of the species. Peirce's pragmatism evades the problem of particular temporality almost completely.

7 Similarly, the Jamesean individual - at least in the two versions of the psychology course - does not really change over life course time. James's famous line about the baby's world as a "blooming, buzzing confusion" (James 1950, 1: 488) comes in the middle of a discussion of perceptual discrimination, not at the beginning of a phenomenological analysis of individual development. Nor did James study whether the "universals" of human psychology change in historical time or across social space, since such changes would imply differences between people rather than properties universal to all of them. This implication would in turn violate one of James's basic premises in his project of inventing psychology - the premise that there was such an abstraction as "an individual," whose universal properties were the proper study of psychology.

8 In short, the early pragmatists did not really address the basic problems of social ontology nor did they worry much about temporality or differences. To the extent that they did consider social ontology, they took either a logicist or an "abstract individualist" position, positions long familiar from the contractarians and central to vernacular American social theory at the time. In consequence, they have little to tell us about the need to combine concerns for ontology and temporality into a single framework. ${ }^{1}$

Between the early and later pragmatists the problems of development and difference became central in American social thought. But they did so in quite different ways, and, more important, their theorists chose very different presuppositions. My earlier remarks presented the problems of development and difference as two aspects of a single issue: 
the need for a viable processual ontology for the social world. But the differing intellectual trajectories of studies of development and difference have made this unity of approach more and more difficult as time passed.

\section{A. Individual Development}

10 Around the turn of the twentieth century, there emerged from a variety of sources a concern with what we would now call developmental psychology - the evolution of the self across the life course. This concern flowered in writers like James Mark Baldwin, Adolf Meyer, and Sigmund Freud. The intellectual sources of the new developmental psychology lay in part in changes internal to the new discipline of psychology itself. The field was pondering the old philosophical debate of associationism versus apriorism, but with novel data from anatomical and physiological studies of the human nervous system. At the same time, some sources of the new developmental concern lay outside the discipline, for example in the newly psychological novel, where writers like Flaubert, Eliot, Tolstoy, Conrad, and William James's brother Henry followed the lead of Dostoyevsky (and other writers of Bildungsromane) away from the realist, social-level analysis characteristic of Dickens, Balzac, and Zola, and towards an intensively developmental account of individual transformation. ${ }^{2}$

11 Alongside those intellectual sources, two great new social institutions also demanded a practical focus on developmental psychology. One was mass schooling, where developmental questions became particularly salient because of the cultural differences that immigration had induced in the school-age population of the United States, differences often misunderstood as developmental differences rather than cultural ones. (The Army Alpha Test debate in 1917-18 was a late example of this misperception. See Carson 1993.) The other source was the mental hospital system, in which hundreds of thousands of Americans lived, and where hereditarian pessimism was giving way to a more optimistic life-course approach in the work of people like Meyer and Freud. This new work facilitated the transfer of methods for "abnormal psychology" to the perplexing plethora of "nervous" diseases then newly common among the general bourgeois population. The Freudian approach would triumph in that expanded, nonpsychotic clientele, of course, but it was in fact only one of many such analyses of the emotional development of the self. ${ }^{3}$

Thus, the problems of education and anxiety guaranteed that the later pragmatists confronted a world obsessed not only intellectually but also practically with individual development and change over the life course. The main academic result of this obsession - the theoretical and experimental literature on developmental psychology - was already extensive by 1900. For example, James Mark Baldwin and others were already experimenting with children (usually their own) to uncover the exact course of mental development. A good deal was "known" about the order in which various skills and abilities developed in childhood, and the beginnings had been laid of a "natural history" of the human individual across the life course. ${ }^{4}$

13 In Baldwin, this theory of individual development was coupled directly with a concept of larger historical flow. Baldwin's profound commitment to evolutionary theory as then understood led him to base his theory of development on Haeckel's notion that ontogeny recapitulates phylogeny. This recapitulation concept recognized two levels of development - those of the individual organism and of the species. The two were 
differentiated mainly by their time scales. The one unfolded in decades, the other in millions of years.

But between these two was nothing. The Haeckel phrase - and the Baldwinian psychology - did not envision processes on some intermediate time scale. Specifically, Baldwin had no concept of the "history of social entities" - the thing we would today call "history." Yet outside psychology, such a "historical" level of process was well recognized at the time. Debates about the nature of history were endemic in the later nineteenth century; we have only to recall Ranke's positivism, Schmoller's economics, Buckle's evolutionism, and the French historical school of Langlois and Seignobos. And this new historicism had a quite specific view of the temporality of history. "History" was typically seen as "larger" than the individual, a conceptualization that would eventually pass uncritically into modern social theorizing as the idea of "levels" of social reality. This "larger" history, in the view of the highly progressivist late nineteenth century historical writers, occurred on a time scale roughly one order of magnitude longer than individual development. It was a matter of hundreds of years, but not of millions. Yet such history went unrecognized in the Baldwinian psychology, which theorized only individual development and species evolution. ${ }^{5}$

Like Baldwin, Freud also developed a complex developmental theory for individuals, in his case a theory of emotional development. Unlike Baldwin (but like Rousseau, in the different case of social inequality), he did this on purely hypothetical principles. That is, rather than extensively observing early childhood behavior, Freud reasoned back from later symptomatology to earlier events, a procedure that obviously involved very strong assumptions about the causal effects of early experience. This procedure seemed in many ways cognate with that of "history" as an emerging discipline, which - as I just noted usually read the past through the lenses of progress and thereby made the past simply the starting place for the present, rather than a period of interest on its own, from which other possible presents might have descended. Because of this correlation of methodologies, we might expect Freud to have come closer than Baldwin to a merged conception of individual development and historical change. ${ }^{6}$

But while Freud's theory of the larger process was not on the heroic evolutionary time scale, it ignored history even in the progressivist sense, much less in the contingent one. In a late series of works stimulated by the great puzzle of the First World War, Freud urged the purely hypothetical history of the "primal horde." As Freud knew perfectly well, the concept of the primal horde was not really historical, but simply projected Freud's theories of individual development onto an indefinite social past. And in discussing civilizational sublimation, Freud returned (still hypothetically) to this indefinite past:

When a child reacts to his first great instinctual frustrations with excessively strong aggressiveness and with a correspondingly severe super-ego, he is following a phylogenetic model and is going beyond the response that would be currently justified; for the father of prehistoric times was undoubtedly terrible, and an extreme amount of aggressiveness may be attributed to him. (Freud 1961 :78)

Like the "state of nature" of the various contractarians, the primal horde concept was an arbitrary fiction, not in any way independent of Freud's developmental theory. Moreover, if the primal horde was not really historical, neither was it in any way particular. Freud himself never seems to have doubted the universality of any of his major conceptions, 
although, to be sure, anthropologists influenced by Freud would soon begin to ask about the possible cultural universality (or limitation) of his theories. ${ }^{7}$

Thus the great developmentalists Baldwin and Freud both more or less avoided the question of contingent and particular "history" in order to pursue a universal concept of individual development. This allowed them to produce very elaborate developmental theories, but at the cost of assuming a universal, historically decontextualized psychology. This new developmental theory provided a crucial context and challenge to evolving pragmatist thinking, by demonstrating how much could be achieved by ignoring the social question in either of its guises: as the question of historical change or as the question of the social differences that arose out of that historical change. ${ }^{8}$

The developmentalists' achievements could not be ignored. The pragmatists read Baldwin attentively, finding much to dispute but also much to absorb, as can be seen from Dewey's review (1898) of Baldwin's magnum opus. And like all intellectuals alive in those years, the pragmatists also read Freud, whose work seemed to destroy any possibility of a nondevelopmental account of emotional life. This encounter with developmental psychology must have strongly prejudiced the later pragmatists against the purely abstract temporalities of the earlier pragmatists, but at the same time they cannot have missed the new ahistoricism evident in the idea of universal sequences of psychological development.

\section{B. Social Differences}

The other great social issue providing a context for later pragmatist thinking was of course the question of social differences, posed in the United States first by the slavery issue and the Civil War, and second by the immense immigration following 1880. Like developmental theories, these discussions of social difference were often in dialogue (sometimes positive, sometimes negative) with the hereditarian approaches to social differences dominant in the 1880s, which were themselves traceable to Darwin and Spencer. ${ }^{9}$

The social differences literature had two major strands. Both were normative literatures, driven by the concern to ameliorate what were perceived as fundamental problems in American society. They are best differentiable by their strategies for that amelioration. One strand would resolve social differences by designing an educational system that would in principle gradually destroy those differences, leaving behind people who were as it were - diverse but not different. They would be liberal citizens, completely equal makers of a social contract. But within that contract they would - it was hoped - make a wonderful and richly rewarding diversity. ${ }^{10}$

This first strand of "social differences" thinking did admit of a simple history of social differences: different peoples come together, encounter one another, and ultimately merge into some new whole without losing their individual uniqueness. In the Deweyan and Americanization versions, this amalgamation would happen through education. In the Robert Park "race relations cycle" version, it would happen through mutual confrontation in which different groups would "educate" each other, which would be followed by assimilation. Either way, the history imagined was usually progressivist and straightforward. It was not massively contingent or complex, nor did it involve truly irreconcilable difference and conflict, or their sequel of social catastrophe. ${ }^{11}$ 

differences, which it thought were not so easily resolved. This view is of course most clearly associated with Marx and the scientific socialists, but it was quite general in the late nineteenth century. Its clearest version was the capital/labor framework, pervasive in American public life - as in European public life - throughout the period. In the United States, most of the other dramatic social differences of the time mapped onto this one quite clearly, so all the versions of difference were more or less equivalent: religion (Protestant capital versus Jewish and Catholic labor), ethnicity (Anglo-Saxon and German capital versus East and South European labor), language (English-speaking capital versus foreign-speaking labor), migrant status (native or old-migrant capital versus new immigrant labor) and so on. The dichotomous difference approach presumed a simple, non-overlapping system of social differences. In its dominant progressive version, the approach assumed that modified social institutions - in particular, the redistribution of wealth - would unmake the dichotomous differences. For adherents of this approach, neither social mobility (under which the interclass line would blur as people moved across it in both directions) nor class conflict (under which explicit confrontation would lead to revolution) would really resolve social differences. There must rather be steady, institutionalized amelioration. ${ }^{12}$

, both strands of thought about social differences in the period were unlike the developmental theories in that they were somewhat historical. They focused on actual processes of change and usually escaped the excesses of Spencerian evolutionism. But other than the Parkian race-relations and ethnicity writings, they were not really contingent or pluridirectional. They were often simplistic in terms of the social differences involved, since the vast majority of differences were mapped onto a fairly simple dichotomy of native/immigrant or capital/labor. They differed chiefly in the kinds of institutional change expected to reconcile difference: long-run demographic processes like education and assimilation in the first case and shorter-run and more directly ameliorative transfer policies in the second case.

That the social differences problem preoccupied the later pragmatists is evident. Dewey's entire oeuvre on education was concerned with social difference and with the challenges that a newly complex urban society presented to traditional educational practices. In a more muted way, Mead's writings also concerned the problem of difference, and as Treasurer of Hull House he was extremely active in progressive affairs. ${ }^{13}$

In summary, the later pragmatists wrote in a context very much shaped by the two great social questions of individual development and social differences and by the literatures responding to those questions. But the two great questions pointed in very different intellectual directions. For they took very different approaches to theorizing social life in liberal, individualist society. One approach to this cat's cradle of causality pulled the strings of determination so as to make evident the trajectories of individuals, in order to understand how to create trajectories that would produce proper citizens for a liberal republic. This was the theory of development and the educational route to reconciliation of social differences.

To be sure, the Parkian assimilation literature had a more potentially contingent and heterogeneous account than the schooling literature, but ultimately it too was captured by a unidirectional progress story, partly through its submergence under the black-white race issue after the ending of immigration in 1925. Overall, the focus on human 
development pushed its theorists in the direction of simple, directed, uncontingent history.

By contrast, the other approach pulled the cat's cradle quite differently, because it aimed to reconcile group differences in the short-term present. The dichotomous theory of social differences focused on the immediate sources of conflict. Although all these differences and conflicts had quite particular and contingent histories, those histories tended to disappear, for the focus was on conflict between present groups whose existence and conflicting interests were taken as self-evident and (tacitly, and perhaps for simplicity's sake) as more or less eternal. The welter of those conflicts was then conceptually tamed and simplified by the dichotomous characterization of society. The great problem with this literature would of course prove to be that when one pulled the cat's cradle of determination by the threads of group conflict, one confronted immediately the problem that individuals were members of not one but dozens of groups, conflicting on different dimensions and in different areas. As long as conflict was unified and dichotomous, the theory was safe. But the superproductivity of capitalism after 1920 permitted a concomitant expansion of consumer society, and this new abundance quickly subdivided and crosscut the seemingly eternal dichotomous conflicts of the late nineteenth century.

In summary, the internal logics of their two problematics rapidly drove these literatures apart. What were useful simplifying assumptions in one literature were foolish premises for the other, and vice versa. In particular, with respect to temporality, one literature found the other short-sighted because it ignored the importance of development, while the other literature found the one dilatory because it hesitated to demand immediate redress. All this arose, in fact, because these two great questions of individual development and social differences were not theorized together. The rewards for narrowing one's assumptions were too great, and so their separation continuously increased.

This social and intellectual background is necessary to specify the context in which the later pragmatists wrote. It is obvious that neither the approach of Peirce nor that of James was helpful in the new context. It made little sense to talk about universal properties of either symbols or psychologies. More particularly, in the new context it made little sense to ignore the development of the various aspects of human psychology across the life course, nor to ignore social differences at a given time. These facts had been clearly recognized by the decade 1900-1910. The later pragmatists thus faced a much more complex intellectual landscape, with two fundamentally different ways to pull the cat's cradle of social causality. They had to rethink completely the analyses of their elders.

\section{The Later Pragmatists}

The later pragmatists - Mead and Dewey chief among them - dealt with this new pair of problems in quite divergent ways. Surprisingly, Dewey - the elder of the two - was the more radical. But this fact probably reflects disciplinary allegiances. Mead was a professional philosopher, while Dewey was not only a professional philosopher, but also a school reformer, a political theorist, and a public intellectual. 


\section{A. Mead on Development and Difference}

32 Mead's social psychology diverges immediately from the union Haeckel (and Baldwin) had proposed. Ontogeny and phylogeny were pulled apart. Mead's account of the origins of symbols and cognition was phylogenetic in general outline; humans developed a larger repertory of significant symbols than other animals. And his analysis of mind remains within this phylogenetic world of pigeons and parrots and dogfights - animals to be contrasted with "what we call a reflective individual" (Mead 1934: 73). Yet much of Mead's argument is phylogenetic only in a limited sense. He compares the different static states of humans and other animals rather than developing a seriously phylogenetic argument of how one kind of system leads to another within a new species, given the evolutionary mechanisms then known. ${ }^{14}$

Thus, Mead's phylogeny was not very phylogenetic. Neither, in fact, was his ontogeny very ontogenetic. As is well known, Mead's account rests on the idea that significant symbols called out the same reaction in the self as in the other. This was simply a philosophically precise elaboration of the Jamesean/Cooleyan looking-glass self concept. But in terms of my earlier argument, it was a form of "abstract individualism," with the slight twist that it was not so much individualist as interactionist. Mead, that is, envisioned an abstract situation of interaction and theorized how such an abstract form of interaction could in principle prove to be the origin of both the individual consciousness on the one hand and the set of general rules constitutive of a social entity (the generalized other) on the other hand. But in accomplishing this intellectual tour de force, Mead used examples and arguments that were about abstract human individuals who were for some unspecified reason without individual consciousness, rather than specifically about babies, who were already at the center of the "origins of mind" debate as it was posed at the turn of the twentieth century by psychologists like Baldwin. Mead's main argument in the Mind section of Mind, Self, and Society was not essentially about education or socialization, but about the abstract logical requirements of a possible account that derived mind from interaction with an outside world in the context of certain limited ego endowments. The Meadean account did succeed in straddling the gap between Kantian apriorism and Humean associationism, but it did so by a logical rather than a developmental argument. There was little ontogeny to it.

In the Self section of Mind, Self and Society, to be sure, there was a distinct sense of ontogeny. Children's games played an important auxiliary role in Mead's account (Mead 1934: 150-64), and the acquisition of the generalized other was construed in explicitly developmental terms. But by comparison with his contemporaries' developmental writings, Mead's developmentalism was vague. One has only to compare Mead with Piaget, whose first works appeared at the same time as Mead was giving the lectures that became Mind, Self, and Society, to see the rapidity with which strong and narrow developmental assumptions - and the banishing of the phylogenetic side of the Baldwin program to philosophy or biology - had enabled developmental psychology to bypass the pragmatists. This transformation was accomplished particularly by Edouard Claparède - $\mathrm{a}$ friend and occasional collaborator of Baldwin's - and above all by Claparède's brilliant student Jean Piaget. By comparison with Piaget's Play, Dreams, and Imitation in Childhood, which although published in 1945 was built on Piaget's research in the 1930s, Mead's account of the role of play in symbols is only very loosely ontogenetic, whereas Piaget, 
pulling the cat's cradle very hard indeed, makes the detailed ontogeny of intelligence into the central process of psychology. Mead was thus in some sense moving backward, towards the abstract individualist position, rather than prioritizing ontogeny over phylogeny as had Claparède and Piaget. ${ }^{15}$

Rather than embrace this new ontogenetic focus on individual development over time, Mead thus remained in the world of abstract philosophical imaginings. His concepts of "interaction" and of "calling out the same response in self as in the other" are concepts like "state of nature" and "primal horde": abstractions employed to make a clear point about the logic of particular situations. Through them, Mead was indeed able to produce self and society out of the same singular process of interaction - surely an intellectual triumph, given the complete dominance of the Enlightenment social ontology with its independent and prior adult individuals. But he accomplished this triumph only by largely ignoring real change over real time, at both the individual and social levels. This backward step may have been the price of his processualizing move.

As for the issue of social differences, the Self section of Mind, Self, and Society occasionally does recognize the non-concentric nature of the "generalized others" in which one participates (e.g., Mead 1934: 157). But Mead did not really consider the resulting problem posed for the self - the need for internal unification of what could be wildly differing self attitudes and consequently the problem those differing selves posed for social solidarity itself. And yet this very issue constituted the main empirical work and theoretical concern of Mead's colleague and friend W. I. Thomas. Thomas taught about attitudes from 1913-14 onward, and the dialogue between personal attitudes on the one side and social values on the other is the central concern not only of the "Methodological Note" of The Polish Peasant but indeed of the text as a whole (Abbott \& Egloff 2008). Also central to that work is an attempt to account for the emergence and fixation of social differences (between groups) in the process of interaction, another of the theoretical processes discussed in the Methodological Note, and a topic ignored even in the social differences literatures discussed earlier. (Differences were there taken for granted.) By contrast with Thomas's robust inquiry, Mead's social theory usually presumed a nested series of concentric generalized others leading up to that most general of generalized others, the League of Nations (1934: 209, 287). Although there are occasionally examples drawing on actual political situations (e.g., 1934: 187-8), these are interspersed with static phylogenetic comparisons referring to the contrast of human experience with that of sentinels in animal herds (1934: 190-1). Mead's argument is abstract, absolutely scalable across all levels of temporal comparison.

Thus we see that the price of Mead's merger of the individual and the social was the forfeiting of a truly temporal account of either the individual or the social level, and more specifically of the emergence and fixation of differences at the social level. It is this problem more than any other that derails any attempt to generalize Mead's pragmatic "socializing" of cognition by, for example, extending it to the question of emotional development. Such accounts would need to parallel Mead's account of cognition, demonstrating the origin of both the personal emotional self and (say) the group emotions of the "madness-of-crowds" type in a single interactive emotional process. But the only compelling accounts of individual emotional life are very strongly developmental. To "socialize" emotional life without recognizing developmental issues would therefore be a self-evident mistake. 
38 Moreover, while the Mead theory of mind and self seems excellent in its abstract perfection, the mind and self of any given individual arise in a context filled with other individuals and selves which are far more fully developed - parents, teachers, and elders - and filled as well with developed institutions like family, school, and workplace. In practice, a realistic general framework cannot ignore the location of development within an already existing and highly particular social process. And it must even confront fixed social differences of a non-functional type - nationalism, for example. In summary, while Mead succeeded admirably at showing individual/society dualism, he did so that the price of removing all particularity. But since particularity is universal, his arguments were necessarily limited. To surpass him, one must pull the cat's cradle not just on the two points of individual and society, but also on a third point - the embedding of each of these in particular lineages of development.

\section{B. Dewey on Development and Difference}

It was of course John Dewey who began this analysis of individual development in particular contexts. His reform of education had very specific origins: it aimed to respond to the disappearance of particular kinds of training that used to occur in most households: sewing, craftwork, woodworking, and so on. Individual development and social change are thus both central to Dewey's thinking, as are social differences. This is perhaps not unrelated to the fact that it was Dewey, too, who pushed the pragmatist program most strongly in the normative direction.

In the first place, Dewey in his educational writings was much more explicitly developmental than pragmatism theretofore. To be sure, he could when necessary write in the earlier, non-developmental style. Human Nature and Conduct (1988) is meant to theorize the psychological structure of a fully developed adult, in the tradition of the great Enlightenment philosophical psychologies like the first book of Leviathan, Locke's Inquiry Concerning Human Understanding, Hume's Treatise on Human Nature, and Kant's three critiques. But even here Dewey cannot avoid putting the character into motion, noting the importance of development in chapters 4 and 5 , and - not by coincidence - raising in the same chapters the issue of social differences. But Dewey is usually a full-blown developentalist, and it is in his early thinking on education - contained in his 1899 lectures on the philosophy of education - that we see his detailed developmental approach for early education. ${ }^{16}$

41 The analysis rests on two great pillars. The first is the idea that education consists of the "adjustment" of the individual to the surrounding society. Education is thus always fundamentally social in its origin and the origin of the self necessarily social. But the self is not merely social. For at the same time, the individual always engages the social through antecedent endowments (e.g., Dewey 1966: 48). Dewey had thus already begun in 1899 to adumbrate the position - which Piaget would soon elaborate - of the dual cycle of assimilation (adjustment of novel input to preexisting endowments) and accommodation (adjustment of self to novel external inputs). ${ }^{17}$

The second pillar for Dewey is the premise that education is never a goal in itself: It is not a specific content, a specific set of skills (or even Deweyan habits) acquired once and forever. In this sense, Dewey's account is completely processual. As he would later argue, all interim ends must eventually become means to other further ends. He thus refuses to 
acknowledge any particular content to education, just as he would later argue in The Public and Its Problems that there could be no once-for-all form of "good government."

Dewey was quite specific about development, giving explicit phases in education in the 1899 lectures (Dewey 1966b: 149). Setting aside infancy, he sees age 3 to about 7 as a first phase, 7 to puberty as a second, puberty to 18 or 20 as a third, and 20-plus as a fourth. In classic Deweyan fashion, these stages are distinguished by their differing relations of means and ends. The first stage is one of "direct experience": no distinctions of means and ends, no distinction of process and product. There is simple immediacy of experience. The second stage is the transition from immediacy to the beginnings of deferred experience, via separation of means and ends, a distinction evident in the shift from play to games. The third period is a period of coming into consciousness of a larger society of which one is a part: a world of inclusive wholes (Dewey 1966b: 158) which define and locate themselves as rules, procedures and generalizations. ${ }^{18}$ The child gains a sense of the large-scale and important, versus the detailed and local, and now conceives of him- or herself as a part of something that is outside and other. A fourth phase is about entering into work: choosing a place where one's skills, abilities, and shortcomings will find optimal expression, "the line of work which is best suited to his capacity and in which he is capable of rendering the greatest service to society" (Dewey 1966b: 159).

Although Dewey was thus strongly developmental, he was less concerned, in the 1899 Lectures at least, with difference. He did not really confront the enormous variety of individual children, perhaps because he was mainly concerned with young children and with the grades in which education was already almost universal in coverage and content. And, looking beyond education, neither did he problematize the fit between young people's very varying abilities and desires on the one hand and the work demanded in the labor force on the other, even though he lived through a period in which much of the craft work that he thought was highly educational was not only stripped from the household (as he had noted, in his arguments on behalf of craft education) but also stripped from the labor force entirely through mechanization and automation. He did speculate that "the mechanic ought to have something within him which would make him more intelligent, more ethical, more cultured in his calling, as well as the doctor or minister or lawyer" (1966b: 172). No doubt he was thinking of the various virtuosi of craft culture: the plumber who has learned from long experience and reflection the complex behaviors of hot water heating systems, for example. But while he may have theorized the idea of craft genius, and indeed although he focused intensively on the loss of household instruction for little children, Dewey did not theorize this shifting work process explicitly, even though it created many of the problems that he wanted education to ameliorate. Thus it is fair to say that Dewey's analysis of social differences did not really deeply affect his analysis of development. ${ }^{19}$

\section{Dewey as Processualist}

Dewey is, however, a committed processualist. An important sign of this is his strong emphasis on the present, combined with his strong commitment to the openness and possibility of the future. For Dewey, education is really an attitude about the relation between self and the non-self world. It is an agreement to continue learning, not to become a dead self through habit. It is a commitment to process. But despite his high hopes for the future, Dewey does not really address the question of how process itself 
maintains ideals and conserves the good, rather than just wandering among new (and possibly meretricious) possibilities. He certainly felt that he (John Dewey) could not foresee the future and that the future would need to makes its decisions for itself, in light of things we could not possibly know now. That was the creed of processualism. But other than mandating adjustment in the future, he is unwilling to specify strategies and criteria for that adjustment. This would prove to be an Achilles heel for his political theories, as it is for any processual politics: there is no obvious way to guarantee avoidance of "adjustment" to totalitarianism and its like.

This processual creed shone especially strong in Dewey's later work on the higher levels of education, in the book Democracy and Education (1916). Here Dewey becomes explicit about lifelong education and has drawn the inevitable conclusion that once we regard education as enduring throughout the whole of life, in a society that is continually changing, we have arrived at the theoretical problem of the mutual constitution of society and individual as particular things, over time. Moreover that problem is not expressed simply in the Meadean form of abstract individualism, but as a question of practical historical experience.

Dewey had thus come to the threshold of a fully particularized processual ontology, embracing both particular individuals and particular social structures in a mutually constituting system. Dewey himself did not, however, directly theorize this ontology. Rather, that task was undertaken by Thomas and Znaniecki's The Polish Peasant In Europe and America, which began appearing two years after Democracy and Education and whose research was contemporaneous with it. The mutual constitution argument pervaded the Methodological Note and the first two books of The Polish Peasant. The study of historically differing institutions pervaded the entire text. And the biographical and developmental approach was implicit in the 200 pages autobiography of the hapless Wladek Wiszniewski, which was the third volume of the original edition. Indeed, The Polish Peasant - whose motivating author was after all a longtime friend and colleague of Mead and Dewey should be regarded as the most comprehensive (if not very clear) statement of a pragmatist approach to empirical social science. It is also the most sophisticated pragmatist text in terms of integrating personal development and institutional change (that is, the necessarily particular histories of individuals and of social entities) into a fully processual social ontology. This argument appears in the center of the Methodological Note and seems to have been forced out of Thomas by Znaniecki (see Abbott \& Egloff 2008), whose social emergentism was rigid enough to counter Thomas's diffuseness and commitment to an almost random processualism. ${ }^{20}$

Thus The Polish Peasant came as close as any pragmatist text to a work showing the mutual constitution of society and the individual as particular things, not as abstractions of the type Mead had envisioned. Yet Dewey himself retreated from the need to theorize these particular histories. By embedding his concept of education within the concept of democracy, Dewey made a crucial move. On the one hand, he moved the pragmatist position towards explicit normative commitment. In one sense, this naturally reflected Dewey's concern for education, which is inherently a normative activity, since it involves choices of what to teach and how to teach it. But in another sense, this commitment derived from the pragmatist desire to judge activity in terms of its consequences and the pragmatist recognition that such judgment is always partly normative, and indeed that therefore any successful social ontology must not only be, as I have just argued, historical 
in both individual and social-entity terms, but also willing to recognize the social process as in part inevitably normative.

\section{Dewey as Normative Democrat}

But by making a normative turn towards democracy, Dewey inevitably had to accept some of the concepts of social ontology implicit in the longstanding philosophical foundations of democracy. These lay in contractarian liberalism, at least as far as most of his readers were concerned. And the social ontology of contractarian liberalism was then and has since remained largely ahistorical. As a result Dewey seems to give up - on the normative side - what he has achieved (in part) on the empirical one. Just as Mead had stepped back from developmentalism and differences to craft his mutual constitution argument for individual and society, so also Dewey seems to pull back from particularities in his attempt to add the normative dimension to his mutual constitution argument.

50 A brief aside is necessary about the inadequacies of the normative ontology of contractarian liberalism. Under the normative ontology of contractarianism, the political world is constituted of equal individuals in a state of nature who have come together to make a society. This coming together is, of course, a normative ideal expressed as a hypothetical history, not an empirical model. But it nonetheless serves to generate the concepts of liberty and of equality before the law which in turn underwrite the legal and political systems that are the empirical foundation of most democratic societies. But the normative ontology of contractarianism in practice thus enacts a legal and political world that is quite at variance with what we know perfectly well is the ontology of the empirical world. Contractarian theory divides the world into an ideal public and political world, and a less-than-ideal private and empirical world. ${ }^{21}$ The normatively ideal side of this ontology comprises free and equal citizens without particular (private) ties affecting their participation in universal political life. The empirical and private ontology - willy nilly comprises differentiated individuals linked through dozens of complexly overlapping groups, wide inequalities associated with numerous different types of stratification, and overdetermination such that politics conducted in terms of one of these bases of stratification has complex knock-on effects through the others. Thus, the normative ontology of contractarianism not only lacks any serious model of complex particularities (which are banished to the private world), it also lacks a serious model of history, of inheritance, of lineage. While all of these things also profoundly shape democratic societies in practice, they are banished by the normative ontology of contractarianism to the almost unanalyzed "private" realm of society. It is a great ideal, but one achieved by sweeping many inconveniences under the rug.

Dewey understood the inadequacy of this simplistic approach. His notion of democracy is both more complex and more processual. He did not think democracy was one thing or one set of institutions, as the heritage of classical liberalism typically thinks. Yet even his own two major definitions of democracy themselves leave serious questions.

In Democracy and Education, the main definition of democracy - the first of two in the this book - comes in Chapter Seven on "The Democratic Concept in Education." Dewey gives two basic standards for democracy (1966: 83): "How numerous and varied are the interests which are consciously shared? How full and free is the interplay with other forms of association?" These standards (diversity and free interplay) are fine criteria for a democracy, but of course there are crucial assumptions. One is the assumption that the 
"various interests" do not include anti-democracy, a matter which would become central, immedately after Dewey wrote, through the rise of fascism.

More subtle and insidious is the second assumption. Dewey has no doubt of the existence of varied interests. Because of that, he does not recognize that in his ideal society, varied interests might actually become scarce. His definition - hardly surprising for a definition propounded in 1916 - takes the existence of great diversity for granted and asks how highly diverse groups can get along. But those diverse interests, whose preservation and interaction are the supposed glory of liberal and democratic society, could perhaps only be created in societies that were themselves relatively closed and even close-minded. Thus, it is a beautiful thing to talk about diverse religions or languages or schools of art getting along with each other. It is quite another to imagine how any individual religion or language and school of art can - within a society committed more or less to eclecticism - come to the coherence and strength that allows it to represent a serious alternative to current religions or languages or schools of art.

This problem of the origin of difference no doubt seemed irrelevant to Dewey. After all, difference was arriving on the steamships every day, and the entire contractarian tradition, buried in a narrowly economic concept of self-interest and frightened by the religious differences that had destroyed Europe 1500-1650, ignored the possibility that the creation of serious cultural or social difference might become a problem. Only the mass society literature - Ortega y Gasset (1932) and others - asked this question (as well they might in an era of strident populism and fascism), and it is striking that they were themselves soon branded as fascists (by the left) for daring to pose it. But in the end, the sources of difference remain a question for Dewey. Granted that in this first definition democracy involves different kinds of people making common cause, the question remains: where does real difference come from?

Dewey's later definition of democracy, in The Public and its Problems, was again twofold, but this time two fold in terms of individual and society.

From the standpoint of the individual, [democracy] consists in having a responsible share in forming and directing the activities of the groups to which one belongs and in participating according to need in the values which the groups sustain. From the standpoint of the groups, it demands liberation of the potentialities of members of a group in harmony with the interests and goods which are common [...]. A good citizen finds his conduct as a member of a political group enriching and enriched by his participation in family life, industry, scientific and artistic associations. There is a free give-and-take; fullness of integrated personality is therefore possible of achievement since the pulls and responses of different groups reinforce one another and their values accord. (Dewey 1927: 147-8)

The difficulty with this definition becomes visible as soon as we begin to try to insert it into real history. Consider the individual first. Across the life course, the individual's responsible share in forming and directing the activities of the groups to which he or she belongs must necessarily vary with the many personal qualities that vary in the life course: intellectual development, education, group-relevant skills and expertise, degree of commitment to the group, and so on. Likewise, the individual's needs will systematically vary: by alternative sources, by ill health and other damages, by prior experiences that have created advantage or disadvantage. Moreover, once we put the individual in motion, we must confront the issues of moral hazard, uncertainty, and discounting, which disturb the simple flow of responsible power and justifiable need. On the social side, the notion that a society's diverse artistic, political, industrial, and 
scientific groups inevitably accord because of cross-cutting pulls is probably wishful thinking, and Dewey was either unaware of or ignored the extensive use of the American political system for set-asides and private benefits for this or that social group, be it ethnicity, gender, race, social class, age grade, or illness risk group. And those are only the synchronic difficulties. Dewey writes as if there is no gain and loss in political life, as if one could count on a rising tide that would raise all boats. One is reminded of Rousseau's remark that true democracy is a government only for angels.

This is surely not to say that Dewey has not identified a great ideal. He has indeed done that, as he so often did. But in point of fact, the American political system handles all these many problems of history and particularity via a legislative and legal system based mainly on procedural rather than substantive safeguards, and one that has not always had a strong record for social equity. We would be well-advised to rethink the very premises of our social contract, embedding it in real time and recognizing the continuous process of group conflict that it represents, as well as recognizing that we should be aiming to produce whole lives that are just (in Dewey's word, democratic), rather than simply thinking about equity moment by moment. There is no automatic inference that equity moment to moment must inevitably produce equity in the long run.

To be sure, throughout The Public and Its Problems Dewey emphasizes the need for experiment and change in political institutions. But he never tells us how those experiments are going to be accomplished and who is to judge (and how) whether they have succeeded or failed. There is today, for example, a state-led movement to call a constitutional convention in the US to force the Federal Government to balance its budget, but those who propose it have begun to realize that other institutions institutions that protect their power like the Electoral College, winner-take-all voting, and the Senate - could in fact all disappear if that convention took a surprising populist direction. Indeed, it is not clear that anyone dares truly experiment with the form of the U. S. government. This follows from another of Dewey's insights in The Public and Its Problems, which is that the chief aim of law is predictability of consequences (1927: 53-4). Experimenting with government is bound to produce enormous unpredictability.

We see then that although Dewey has done well in recognizing development, and has maintained the Meadean coplanar processualizing of individual and society, his encounter with the contingencies of group history is not as solid, and as a result his views of current group differences are adrift. Moreover, he has not completed a contingent theory of individual development, but has left development mainly universal, largely in order to reconcile his theory with requirements arising from the simple normative ontology of contractarianism. All that said, of the great pragmatists, he alone really makes the transition to processualism. If he failed to draw some necessary conclusions, that is because the initial leap is one of such extraordinary daring.

\section{Requisites of a Processual Ontology}

The analysis here makes clear that much of pragmatist social theory, although quite processual, proceeded in the modality of "abstract individualism." It accepted the notion that society comprised adult individuals whose qualities could be understood as given in a moment. 
61 Mead's attack on the vernacular social theory of the time placed even such an abstract individual on the same ontological level as society. He challenged the vernacular view at its strongest point: its belief in the origins of mentation through personal experience on an associationist basis. By arguing that mentation was first a social act and only later an individual one, Mead turned the vernacular on its head. Individual and society were now coplanar.

But Mead accomplished this by working chiefly in an abstract rather than a concretely processual manner. This almost certainly reflected polemical necessity. Anglo-Saxon social and legal thinking has worked in the vernacular of the English and French contractarians since the early eighteenth century. To engage it one must talk its language, which includes not only the contractarian logic but also the mechanically associative psychology that could produce - independently of any social experience adult consciousnesses that could come together to make a contract. Society was thus in that vernacular a somewhat static collection of mature individuals rather than a continuous process in which young people were first entering families and then entering the larger society (changing both of them in the process), then aging and changing further, then growing old and dying. By showing that even on its own terms this view was incoherent and probably erroneous, Mead erased the vernacular relation of individual and society. But he did not then move on to place those elements in a new and fully processual interpretation. Dewey by contrast did so, largely because of his particular subject focus of education. Although Human Nature and Conduct proceeds on traditionally abstract lines, all of Dewey's writings on education are strongly developmental.

Two things seem important about pragmatist developmentalism. First, it does not touch the topic of emotion. The pragmatist philosophical program concerned the relation of thought and action. Emotions make hardly any appearance in Peirce. They command a characteristically brilliant chapter of James, who conjectured that emotion was merely the cognition of a state of bodily feeling, thereby turning another of the vernacular truths on its head (James 1950, 2: 449). But one feels that the analysis is clever rather than persuasive, and one doubts whether James himself - a man given to lengthy and profound depressions - can have actually believed his own theory. This wilful ignorance of emotion continues through to Dewey. The final judgment of the pragmatists on emotions may well be Dewey's remark in Human Nature and Conduct (1988: 177) that "alas, emotion without thought is unstable. It rises like the tide and subsides like the tide irrespective of what it has accomplished." There is no clearer statement of the pragmatist credo that accomplishment is the test of all things.

64 It was rather Freud who made a decisively emotional account of human ontogeny. Whatever we may think of the contents of his theory, it - and the broader life course concept of development of which it is the most elaborated exposition - have triumphed absolutely as vernacular theories of modern emotion and indeed of the modern life course. Yet the pragmatist response to Freud, and even to life course psychological theories more broadly, is almost nonexistent.

65 The other main quality of pragmatist developmentalism is something shared with Freud and indeed with most other developmentalists. This was an abstract approach to development itself. Freud claimed that his theory of emotional development was universal. Dewey, as we have seen, could often ignore individual differences between children. More broadly, the vulnerability of individual development to the kinds of differences in culture, family, and social institutions that were characteristic of the 
United States at the turn of the twentieth century is largely unnoticed. That is, while Dewey integrated the concept of development very clearly into the social ontology of the pragmatists, he did not do so while simultaneously recognizing the vast differences within the population both in terms of what they brought to the society and in terms of the positions in the society available for them to occupy. Different kinds of families produced different kinds of ontogenies, and the perpetual changes of a modern consumer society - in jobs, in goods, in morals - meant that development could take numerous turns. Indeed, those differences and turns have become one of the great political issues between the American left and right.

More generally, the pragmatists also failed to theorize the various forms of social difference themselves: ethnicity, religion, gender, age, class, ability, and so on. Even Thomas and Znaniecki saw only distantly the complex interactions and overlaps of these things, with the result that the "developmental" story for social entities - the logical equivalent of individual ontogeny - all too often evinced a gradualist "loss-of-tradition" approach of the kind Dewey skewered in the opening sections of The Public and Its Problems. Yet Dewey's own concept of multiple publics does not in fact sustain a serious analysis of social differences.

In short, the pragmatists made the move to development on the one hand, and, to a limited extent, to a real history on the other. But they did not really view difference in full round, either as presenting problems to be solved or as being, in itself, something that could possibly weaken or disappear. But fascism and most forms of communism soon eradicated much social difference, with extraordinary consequences. The pragmatist social ontology was dangerously irrelevant in a world filled with unitary states of left and right, which called themselves democratic but were not so in practice. Indeed, one of the issues raised by totalitarianism was whether the achievement of a society's modernity might itself not require, in historical terms, the virtual destruction of the free experience of whole cohorts of that society. This was a process Dewey could and did judge, certainly, but it was not something of which his theory could make sense.

Here again we confront the prices of Dewey's admirable theoretical commitment to normative thinking in general and to democracy in particular. Dewey recognized that complexifying the purely empirical conception of the social world was not enough. To be sure it was essential to recognize development. And, to a certain (but not sufficient) extent, he saw that it was important to imagine that development as happening in parallel with dramatic changes in social institutions. But Dewey also saw that our social ontologies themselves involve normative judgment - right and wrong - because the social process is itself a process of values (as the pragmatists would have said, the social process is about the quality of the consequences of our actions). Yet when he chose a normative ontology he tended to slide back into the familiar world of contractarianism, which obviously describes a world that never was and can never be: a world without history, without particularity and difference, without development. This makes moral judgment relatively easy, and provides familiar terms for one's audience.

But it means that his normative theory is adrift. In the first place it doesn't tell us anything about the vast proportion of the world that is not democratic or liberal and shows no sign of becoming so. In the second place, it doesn't tell us anything about the everyday politics of the nation, which mainly concerns conflicts between complexly overlapping social groups, and in particular those groups' attempts to remove their concerns from the cut-and-thrust world of everyday politics (the private world of the 
contractarians) and to get them onto the list of things that are protected and sustained by universal public rules and transcendental legitimacies (the public world of the contractarians). Nor does Dewey really provide us with anything like an ontological framework for thinking about the succession of these groups in time.

We come then to the end of this review with a number of new requisites for a processual ontology. The first is that it recognize individual development and life-course trajectory as essential to any general theory of society. The second is that this trajectory not be conceived in simplistic directional terms, as in the functionalists' theory of socialization. It must be seen as a complex and contingent system, with regularly patterned internal contingencies. The theory of age structure, the lexis diagram, and such tools must be essential parts of this ontological approach. Third, a similarly ontogenetic approach must be taken to social entities, with the additional proviso that their overlapping and shifting topology requires tools not yet invented to extend the kind of demographic approach we have used for biological individuals.

71 Fourth, and most important, we must refuse to allow ourselves to choose any one of these aspects of analysis as primary. For that is the danger of pure ontogenetics, as it is of pure organization theory, and so on. The reason pure developmentalism fails is that by pulling the cat's cradle purely in the direction of trajectory, it uses up all the degrees of freedom in the system for that one project. But in fact, organization theorists, or pure demographers, or others could pull the cat's cradle in other directions and exhaust those same degrees of freedom in different ways. (Ecological theories - for which I am myself well known - are an equally obvious example.) But the degrees of freedom can be exhausted only once, and that is by a social process in which both of individual and social developments are mutually conditioning each other, and in which the theoretical expectations we might generate from a theory based on only one side are preempted by changes on the other. This is the great insight we must take from Mead. It is correct that the individual and the social derive from the same process of interaction. But they do so not under abstract but under very particular circumstances. And this very particularity is what makes their mutual interdependence so difficulty to theorize. But also so worthwhile. Our task is to understand the nature of the cat's cradle itself, not to find out what happens when we pull it in one theoretical direction. ${ }^{22}$

\section{BIBLIOGRAPHY}

Аввотт A., (1982), The Evolution of American Psychiatry, 1880-1930, Unpublished PhD dissertation, University of Chicago.

Аввотт A., (1997), “Of Time and Place,” Social Forces 75, 1149-82.

Аввотт A., (2016), Processual Sociology, Chicago, University of Chicago Press.

Aвbott A., \& R. N. Egloff, (2008), “The Polish Peasant in Oberlin and Chicago,” American Sociologist $39,217-58$. 
ALLPORT G. W., (1937), Personality: A Psychological Interpretation, New York, Henry Holt.

BALDWIN J. M., (1893), Elements of Psychology, New York, Henry Holt.

BALDWIN J. M., (1897), Social and Ethical Interpretations in Mental Development, New York, Macmillan.

BALDWIN J. M., (1903), Mental Development, New York, Macmillan.

BALDWIN J. M., (1915), Genetic Theory of Reality, New York, Putnam.

BARNES H. E., (1962 [1937]), A History of Historical Writing, New York, Dover.

BENNOUR M., \& J. vonÈche, (2009), “The Historical Context of Piaget's Ideas,” in U. Müller,

J. I. M. Carpendale, \& L. Smith, (eds), The Cambridge Companion to Piaget, Cambridge, Cambridge

Unviersity Press, 45-63.

BOWLER P. J., (2003), Evolution: The History of an Idea, Chicago, University of Chicago Press.

BREISACH E., (2007), Historiography, Chicago, University of Chicago Press.

BROUGHTON J. M., \& D. J. FREEMA-MOIR, (1982), The Cognitive Developmental Psychology of James Mark Baldwin, Norwood, NJ, Ablex.

CARSON J., (1993), “Army Alpha, Army Brass, and the Search for Army Intelligence," Isis 84, 278-309.

DEEGAN M. J., (1988), Jane Addams and the Men of the Chicago School, 1892-1918, New Brunswick, NJ, Rutgers University Press.

DEWEY J., (1898), Social and Ethical Interpretations in Mental Development, by James Mark Baldwin, Philosophical Review 7, 398-409.

DEWEy J., (1927), The Public and Its Problems, Columbus, Swallow.

DEWEY J., (1966a [1916]), Democracy and Education, New York, Free Press.

DEWEY J., (1966b [1899]), Lectures in the Philosophy of Education, New York, Random House.

DEWEY J., (1988 [1922]), Human Nature and Conduct, Carbondale, Southern Illinois University Press. DYKhUizen G., (1973), The Life and Mind of John Dewey, Carbondale, Southern Illinois University Press.

FREUD S., (1960 [1921]), Group Psychology and the Analysis of the Ego, New York, Bantam.

FREUD S., (1961 [1930]), Civilization and Its Discontents, James Strachey (trans.), New York, Norton.

FREUD S., (1962 [1923]), The Ego and the Id, Joan Riviere (trans.), New York, Norton.

GREENWOOD J. D., (2004), The Disappearance of the Social in American Social Psychology, New York, Cambridge University Press.

GROB G., (1983), Mental Illness and American Society, Princeton, Princeton University Press.

HOFSTADTER R., (1944), Social Darwinism in American Thought, Philadelphia, University of Pennsylvania Press.

HOFSTADTER R., (1955), The Age of Reform, New York, Vintage.

HUEBNER D., (2014), Becoming Mead, Chicago, University of Chicago Press.

JAMES W., (1950 [1890]), The Principles of Psychology, two volumes, New York, Dover.

JOAS H., (1985), G. H. Mead, Cambridge, MA, MIT Press. 
KARDINER A., (1945), The Psychological Frontiers of Society, New York, Columbia University Press.

LEWIS J. D., \& R. L. SMITH, (1980), American Sociology and Pragmatism, Chicago, University of Chicago Press.

MALINOWSKI B., (1955 [1927]), Sex and Repression in Savage Society, Cleveland, Meridian Books.

MEAD G. H., (1934), Mind, Self, and Society, Chicago, University of Chicago Press.

ORTEGA Y GASSET J., (1932), The Revolt of the Masses, New York, Norton.

PARK R. E., (1950), Race and Culture, Glencoe, IL, Free Press.

PARK R. E., \& E. W. BURGESS, (1921), Introduction to the Science of Sociology, Chicago, University of Chicago Press.

PIÉRON H., (1941), “Edouard Claparède," Revue de métaphysique et de morale, 48, 150-2.

RODGERS D. T., (1998), Atlantic Crossings, Cambridge, MA, Harvard.

ROHEIM G., (1952), The Gates of the Dream, New York, International Universities Press.

RYAN A., (1995), John Dewey and the High Tide of American Liberalism, New York, Norton.

SEWNY V. D., (1945), The Social Theory of J. Mark Baldwin, New York, King's Crown Press.

SPENCER H., (1873-1881), Descriptive Sociology, New York, Appleton.

THOMAS W. I., \& F. ZNANIECKI, (1918-1921), The Polish Peasant In Europe and America, vols 1 \& 2, Chicago, University of Chicago Press. Vols 3-5, Boston, R. G. Badger.

TYACK D. B., (1974), The One Best System, Cambridge, MA, Harvard University Press.

VIDAL F., (1994), Piaget Before Piaget, Cambridge, MA, Harvard University Press.

\section{NOTES}

1. Of course there is much more to say about these topics in the early Pragmatists. I mention them here briefly for the sake of completeness in an analysis mainly aimed at their successors. Note that the dominant social thought of the time in the Anglophone world was Spencer's. Spencer's position on development and difference might seem to resemble James's in its abstract individualism, particularly in Spencerism's vulgar version as Social Darwinism. But Spencer's Descriptive Sociology volumes contain comprehensive functionalist and institutionalist accounts of hundreds of societies. Spencer was in fact obsessed with social differences, but dealt with them in functionalist terms, more than historical ones.

2. For a discussion of the literary sources of the new approaches to behavior, see Abbott \& Egloff 2008.

3. On mass schooling, see Tyack 1974. On the mental hospitals, see Abbott 1982, and Grob 1983.

4. Baldwin's major works are Elements of Psychology (1893), Social and Ethical Interpretations in Mental Development (1897), Mental Development (1903), and Genetic Theory of Reality (1915). Secondary works on Baldwin include Sewny 1945 and Broughton \& Freeman-Moir 1982.

5. A dated but comprehensive and still useful history of historical writing is Barnes 1937. For a contemporary account, see Breisach 2007.

6. It is the "middle Freud" who has this methodological resemblance with history, of course. The early Freud of "psychic energy" and the later "pseudo-historical" Freud are both far from this psychodynamic conception rooted in hypothetical analyses of a past whose chief warrant was its plausibility given the symptomatology of the present. 
7. Examples are Malinowski (1927), Kardiner (1945), and Roheim (1952). The relevant Freud texts are The Ego and The Id (1962) and Group Psychology and the Analysis of the Ego (1960).

8. On the loss of the "social" side of psychology, see Greenwood 2004. The "universal psychology" account of personality was simultaneously systematized and attacked in Allport's famous text of 1937. On the one hand, the book is an attack on absolute psychological universalism. Allport said psychologists were "enthusiastically at work on a somewhat shadowy portrait entitled the generalized human mind"' (Allport 1937: vii). On the other. Allport aimed to pull all the "nomothetic constructs" of his colleagues into a single (and presumably universal) thing called "the personality," which involved social difference only insofar as it affected that personality. The book was thus making a synthetic, but still universal claim. Allport did argue that this universal quality of having a personality was done differently by every individual. He was thus accepting the fact that it is universal to be particular, but only for the case of the personality. But this personality is a universal, ahistorical thing - in the book's closing words (1937: 566) "[The individual] stuggles on even under oppression, always hoping and planning for a more perfect democracy where the dignity and growth of each personality will be prized above all else."

9. The literature on these developments is enormous. A classic text is Hofstadter's Social Darwinism in American Life (1944).

10. The greatest statement in this literature was of course Dewey's Democracy and Education (1966a). The rather skeptical secondary literature starts with Tyack 1974.

11. The basic Park sources are Park 1950, and Park \& Burgess 1921.

12. Again the secondary literature is large and again it begins with Hofstadter (1955). See Rodgers 1998 for a more recent general analysis.

13. Biographical sources on Mead include Joas 1985, and Huebner 2014. See also Lewis \& Smith 1980, and Deegan 1988. On Dewey, see Dykhuizen 1973, and Ryan 1995.

14. A standard history of evolutionary thought is Bowler 2003. Note that Mead's texts predated what is usually called the "modern evolutionary synthesis" of the 1930s, in which Mendelian genetics was firmly articulated with Darwinian theories of variation and selection.

15. For biographies of Claparède and Piaget see, respectively, Pieron 1941 and Vidal 1994. Piaget was born in 1896 and thus was about thirty years younger than Mead. But he was extremely precocious, and his first monographs (Le langage et la pensée chez l'enfant, Le jugement et le raisonnement chez l'enfant, and La représentation du monde chez l'enfant, date from 1923, 1924, and 1926 respectively. The magisterial La naissance de l'intelligence chez l'enfant dates from 1936).

16. It was apparently an occasional practice to have the courses of major lecturers recorded by student stenographers (hence the dozens of Mead transcripts discovered by Daniel Huebner (2014: 233-43). In 1963, Richard D. Archambault discovered by happenstance a transcript of Dewey's 1899 lectures in the Grinnell College Library and prepared the published edition discussed here.

17. The names of these processes - well-known to any reader of Piaget - came from Baldwin's Mental Development in the Child and the Race. On Piaget's antecedents, see Bennour \& Vonèche 2009.

18. Dewey, too, was thus a theorist with a concentric view of social units. It is not clear whether this was for him a strong personal position or a mere analytic convenience.

19. The crucial difficulty here was that the industrial workers tended to acquire skills strongly related to particular technologies and untransferable from one technology to another - mule spinners were a classic example, but there are many others. Physicians and other professionals, by contrast, were able to learn skills that would last a lifetime or that could be updated steadily and systematically across the life course.

20. A long and partisan literature has attempted to distinguish the contributions of the two authors to this magisterial work. A review of the primary material and of Thomas's prior work makes clear that the main architecture and core ideas of the text - its problematics, its genre, its style, and, above all, the pragmatists themes of processualism and mutual-constitution - were 
longstanding themes in Thomas's life and work, dating from well before his encounter with Znaniecki. See Abbott \& Egloff (2008: 231-3).

21. The division in clearest in Rousseau's Social Contract, e.g., in the discussion of equality book II, Section xi, which opposes political equality to economic and social inequality. More generally, the division is clear in the distinction of the general will, which emerges from equal citizens and cannot err, and the private wills of individuals. From this distinction comes Rousseau's explicit contrast of the general will and the "will of all,' which is the mere sum of private wills (in II: iii).

22. I have myself begun to attempt this theory in the various essays of Processual Sociology (Abbott 2016), carrying forward arguments I have made in several earlier works. Successful analysis must start from the premise - common to Mead and Dewey - that causality happens in the present and that, as noted in the present paper, all influence from the distant past must come through the continuous encoding of past effects into the immediate present via a process of encoding. The first task is then to explain how such a continuously changing world - a world of events - can exhibit so many signs of stability. The second is to trace the consequences of the fact that there is no one single time-space present, but rather an extended space of presents through which causes and actions travel to distant events they may ultimately affect. Such ontological issues are canvassed in the early chapters of the book, while the later chapters begin to address the normative issues that preoccupied Dewey. Nonethless, the book is only a series of beginnings on the main enterprise. I am currently working on a more formal exposition.

\section{ABSTRACTS}

In this paper I shall examine how the pragmatists regarded the context of a single self in time (the problem of personal development over the life course) and the context of a single self in social space (the problem not only of surrounding individuals but also of surrounding and fundamentally different groups). After a quick glance at the ontologies of the earlier pragmatists, I discuss the problems of individual development and social difference as they emerged societywide during and after the first pragmatist generation. Having specified these problems, I can set the second pragmatist generation in the context they provide. The paper concludes with a discussion of the centrality of accounts of development and difference in a processualized social ontology.

\section{AUTHOR}

\section{ANDREW ABBOTT}

University of Chicago

aabbott[at]uchicago.edu 